
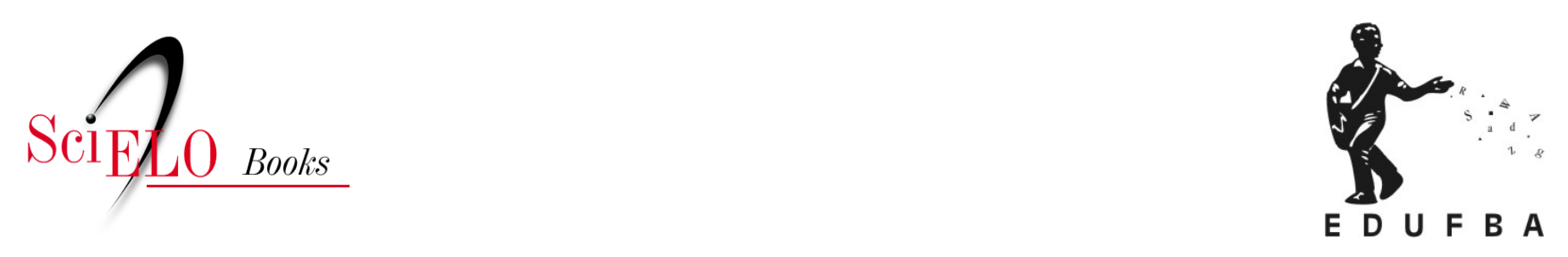

\title{
"Nem toda a gente gosta do diferente": literatura, (de)formação do leitor e diversidade
}

\author{
Emerson Inácio
}

\section{SciELO Books / SciELO Livros / SciELO Libros}

INÁCIO, E. "Nem toda a gente gosta do diferente": literatura, (de)formação do leitor e diversidade. In: MESSEDER, S., CASTRO, M.G., and MOUTINHO, L., orgs. Enlaçando sexualidades: uma tessitura interdisciplinar no reino das sexualidades e das relações de gênero [online]. Salvador: EDUFBA, 2016, pp. 179-199. ISBN: 978-85-232-1866-9.

https://doi.org/10.7476/9788523218669.0010.

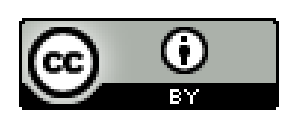

All the contents of this work, except where otherwise noted, is licensed under a Creative Commons Attribution $\underline{4.0 \text { International license. }}$

Todo o conteúdo deste trabalho, exceto quando houver ressalva, é publicado sob a licença Creative Commons Atribição 4.0. 


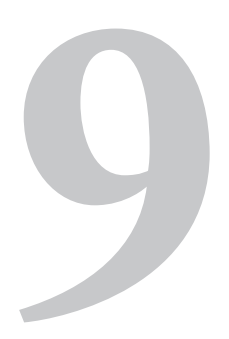

\title{
"Nem toda a gente gosta do diferente":
}

\author{
literatura, (de)formação do
}

leitor e diversidade ${ }^{\mathrm{I}}$

\author{
渵 \\ Emerson Inácio
}

Em seu ensaio A literatura e a formação do bomem, o crítico literário Antonio Candido conduz o foco de seu pensamento para a função humanizadora que a literatura tem a capacidade de cumprir na vida das pessoas, enfatizando sempre que aquela forma estético-discursiva favoreceria à percepção, pela leitura, do quão podem

${ }^{1}$ O título desse ensaio provém de um verso de "Como Tu", da poetisa portuguesa Ana Luísa Amaral, longo poema em que, pressupondo que seu leitor trata-se de crianças, a autora discute, de maneira singela, a questão das diferenças identitárias e sobre como o afeto é capaz de superá-las. 
ser e se tornar sensíveis são as pessoas em função da leitura de um texto literário. Candido, de certa forma, acompanha neste ensaio a concepção oitocentista - e permanente ainda em certa medida - de que o texto literário traria em si, de certa forma, uma capacidade "formadora”, ou seja, de fazer redundar dela indivíduos melhores, conscientes dos grandes valores sociais, morais e humanos necessários à existência das famílias e da sociedade. Entretanto, hoje sabemos que, diferentemente daquilo em que se acreditou por muitos séculos, o texto literário e a "instituição" literatura não tem nem culturalmente nem politicamente o peso que teve durante boa parte da história da escrita e da leitura. Pelo contrário, hoje em dia concorre com outros suportes, cuja capacidade de formar, indubitavelmente, é bem mais eficaz que a forma escrita da linguagem e, porque não dizer, muitas vezes bem mais acessível que um objeto como o livro.

Estaria apenas reforçando o ideário defendido por Candido se eu dedicasse este meu exercício a valorar o texto literário na sua intencionada ou não capacidade de interferir na conformação da cidadania. Interessame, ao par disso, pensar a função reformadora ou, talvez, deformadora que a literatura tem, não só de se demarcar como uma outra linguagem distinta das mídias e suportes mais usuais, mas sobretudo como forma de linguagem em que se estabelece também a diferença: pela exposição daquilo que o senso comum majoritário consideraria não literário, não digno de representação e antissublime é a que a literatura, efetivamente, hoje se faz. Assim, não desejo aqui discutir nem o suposto adultério de Capitu nem sequer os trágicos perigos a que Luísa fora exposta ao dedicar parte dos seus dias à leitura dos romances românticos oitocentistas, mas, pelo contrário, observar como o texto literário pode, a partir dos "restos" sociais e culturais, do erótico, do inusitado, do transgressivo, e mesmo da exposição de formas outras de afeto, propor uma deformação dos leitores, capacitando-os a perceberem a existência de discursos baseados na diferença e na diversidade em todos os seus âmbitos. Aqui entendo por "deformação" uma noção que vai além da perda da forma, mas sim como um procedimento necessário à formação dos indivíduos para que percebam a 
capacidade da linguagem de, saindo dos eixos, transbordando, indo além dos formatos pré-estabelecidos, ensejar a construção de juízos críticos a cerca do mundo.

Noutras palavras: a literatura pode ir além da "função humanizadora" apontada pelo crítico literário e sociólogo Antonio Candido, favorecendo, a partir dessa capacidade de deformação, a construção de discursos que contribuam para sistemas de igualdade, tolerância e respeito às diferenças sejam elas quais forem, não só no âmbito escolar, mas no universo maior da cultura no qual a literatura está discursiva e esteticamente inscrita. Nesse sentido, e palmilhando obras como a de António Botto ( $O$ Livro das Crianças e Histórias do arco da velba) e Ana Luísa Amaral ( $A$ tempestade e Como tu), bem como outros autores, brasileiros inclusive, que trazem ao corpo de sua produção a problematização e/ou as tensões de gênero e sexualidade, pretende-se, assim, entender como o cânone literário pode ser um efetivo e transgressor elemento de (de)formação de identidades outras, distantes da norma e do regramento próprios de uma cultura heterossexual e machista, apontando para o queering identitário. Noutras palavras, de forma paralela ao exercício de construção identitária que promove, favorecendo a criação de um ethos para si mesmo, o cânone literário pode, também, ser "lido a contrapelo" de forma a nos possibilitar a apreensão de discursos e formas não normatizadas e não normalizadas a partir dos textos literários que o compõem.

De fato, toda a vez que aludimos a existência de um "cânone" - seja ele qual for e compreendendo quaisquer matizes - falamos necessariamente num duplo movimento: inicialmente, trata-se de um processo de escolha e seleção efetivado por leitores cujo gesto de leitura e cuja posição social/ ideológica/política/cultural lhes permite interferir ou, senão, determinar que obras podem ou não pertencer a esta lista de “eleitas”. Nesse procedimento, a eleição daquilo que pertence ao cânone corresponde, ainda, a um conjunto de "regras" que tendem a facilitar a seleção ou a, pelo menos, favorecer a construção de um edifício estético com horizontes prédeterminados e que visam a conformação de discursos tais como o da 
nacionalidade. A segunda laçada dirá respeito ao fato de que o cânone é ideologicamente prescritivo, uma vez que determina o que deve e o que pode ser lido, bem como se erige tendo como bases não apenas valores estéticos e artísticos, mas também outros valores que subjazem ao tecido social e cultural de qualquer povo. Poderíamos, ainda, pensar que se trata de um procedimento que visaria eleger aqueles textos que de alguma forma reforçariam valores ou ideais, em situação correlata ao que acontece aos textos bíblicos, de onde, aliás, a literatura toma a noção de cânone por empréstimo. Se tomarmos a questão por este ponto de partida, o cânone se justificaria, como a bíblia, pela prescrição de obras que favoreceriam a formação dos indivíduos, proporcionando-lhes uma espécie de resistência tanto a discursos que não conformariam o panorama estético aduzido pelo cânone, como também reforçaria a ideia de que os textos que o compõe carregariam os valores necessários à construção moral e cultural desses mesmos indivíduos.

Redunda desses dois processos o jogo de exclusões atinentes à formação canônica, uma vez que não lhe pertencer significa, em muitos casos, o esquecimento de certas obras no correr da história e a dificuldade de construírem ou negociarem sentidos com o concerto cultural do qual estão excluídas. Ou seja, se tomarmos o cânone literário brasileiro, no qual percebemos a ausência tácita de mulheres, indígenas e negros, vemos que o período de sua formação - o século XIX - excluía do acerto cultural justamente aquelas figuras marcadas pela diferença e que não carregariam, de fato, valores sociais e culturais que reforçassem a construção de uma "nacionalidade", qual a defendida por aquele cânone que se formava. Da mesma forma, o cânone que se formaria naquela altura refletiria os procedimentos e processos de subalternização aos quais aqueles atores sociais estavam submetidos.

O ponto de fuga do próprio cânone é que ele, algumas vezes, elege e inclui em si formas e discursos que destoam do arranjo que ele mesmo defende, como é o caso, na lírica medieval galego-portuguesa, das Cantigas de Escárnio e Maldizer. Se por um lado tais cantigas, cujo tom satírico 
apontaria para certo reforço dos presumíveis valores culturais e morais da época em que circularam, por outro denotam estética e socialmente a existência de formas de comportamento e expressão que destoavam da tônica cristianizada própria da Idade Média europeia e mesmo da tópica amorosa, como o vemos nas Cantigas de Amor e Amigo. Funcionando como um canto paralelo à norma, as cantigas satíricas vinham dar conta, de certa maneira, à inflexão cultural que determinava o que poderia e deveria ser dito, bem como quem e o que poderia ser literariamente representado na forma lírica dessa poesia, dando, no campo poético, vazão às outras e diversas experiências, que não as apenas ligadas a um ideal sublime de amor. Ao decantarem o sexo, o profano, o erótico e ao lançarem mão da linguagem comum e cotidiana, sem retoques metafóricos, faziam do jocoso um instrumento que deformava a ordem, bem como instaurava a possibilidade de se fazer representar práticas impedidas de circularem em textos de carácter amoroso, como o é, de fato, a representação que vemos a seguir, na Cantiga de Afonso Anes de Cotom:

\author{
Marinha, ende folegares \\ tenh'eu por desaguisado; \\ e som mui maravilhado \\ de ti, por nom rebentares: \\ ca che tapo eu [d]aquesta minha \\ boca a ta boca, Marinha; \\ e destes narizes meus \\ tapo eu, Marinha, os teus; \\ e das [mias]mãos as orelhas, \\ os olhos, das sobrencelhas; \\ tapo-t’ao primeiro sono \\ da mia pissa o teu cono, \\ e mi o nom veja nengum,
}


e dos colhões [esse] cũ,

como nom rebentas Marinha!

Observemos que o enunciador indiretamente alude às capacidades corpóreas e sexuais de próprias e da amante, visto que, ao dar relevo ao fato de Marinha não "rebentar” - ou seja, não se sentir machucada com as "cobridas", 3 tapadas, do amante - enaltece não sua mestria amorosa, gesto próprio da lírica amorosa medieva -, mas a sua potencia sexual associada à disposição daquela mulher para todo o tipo de coito. Aliás, embora seja o enunciador aquele que fala sobre o ato sexual, indiretamente vemos que esta mulher, embora silenciada textualmente, discursiviza-se na vivência plena de um corpo que sente, goza, vibra e que leva o eu poemático a repetir "como nom rebentas Marinhas", ora em tom de dúvida, ora de admiração. Esse corpo que não fala no poema, parece "folgar" (alegrar-se, comprazer-se), em lugar da lutuosa dor de amor que vemos representada em tantas outras cantigas e que, de fato, apaga o corpo feminino ao restringi-lo a apenas algo cujo sentido só se enseja na presença (e na saudade) do amado. Isto sem contar nos múltiplos usos sexuais prazerosos a que este corpo feminino parece se propor, a ponto de deixar o enunciador "desaguisado" (sem guia, sem rumo) e "maravilhado" com a destreza sexual de Marinha, a que se complementa, ainda, à mestria sexual e amorosa do próprio trovador. A figura encarecida na cantiga, Marinha, provavelmente

2 "Marinha, o teu folgar /tenho eu por desacertado,/e ando maravilhado /de te não ver rebentar;/pois tapo com esta minha /boca, a tua boca, Marinha;/e com este nariz meu,/tapo eu, Marinha, o teu;/com as mãos tapo as orelhas,/os olhos e as sobrancelhas,/tapo-te ao primeiro sono;/com a minha piça o teu cono;/e como o não faz nenhum,/com os colhões te tapo o cu./E não rebentas, Marinha?". Versão de Massaud Moisés. A versão original em galego-português está registrada no Cancioneiro da Biblioteca Nacional (Portugal) sob o número 1617. Disponível para consulta em <http://cantigas.fcsh.unl.pt/cantiga.asp?cdcan$t=1643 \& p v=\operatorname{sim}>$. Acesso em: 15 fev. 2016.

3 Forma popular encontrada em diversos povos falantes da língua portuguesa e que indica, metonimicamente, o ato sexual. Seu uso mais corriqueiro diz respeito, entretanto, ao ato reprodutivo dos animais de criação extensiva. 
teria sido uma soldadeira, ou seja, uma mulher que acompanhava os regimentos militares medievais, oferecendo-lhes seus serviços domésticos, inclusive os sexuais, sendo, portanto, uma imagem feminina a que era permitido o uso de seu corpo. Notemos, apenas, que este uso, segundo o trovador, é um uso pleno, uma vez que o "folegar" (folgar) de Marinha denotaria uma posição feminina não passiva diante do uso comercial feito de seu corpo, o que no caso, para ela, ultrapassaria o utilitarismo próprio da prostituição pela indicação do seu prazer no intercurso sexual.

Sexual, não amorosa! E eis aqui um signo da deformação a que antes aludi: obliterados pela representação do amor cortês, bem como por sua ideação romântica, outras formas poéticas como o maldizer, o escárnio e mesmo as cantigas de amigo encerram a materialização de vivências que corrompem o imaginário acerca da Idade Média, uma vez que demonstram a um leitor empírico que nem só de amores sublimados viviam os seres àquela altura, mas também de toda a sorte de fetiches e vivências ainda hoje consideradas transgressivas, como o prazer anal, por exemplo. O leitor, no caso, vê deformada a (sua) visão canônica que fizera preponderar um imaginário medieval em que o corpo inexiste e com isso, também, o sexo, o prazer e o gozo. Ao lado desse pormenor, outro que gera interesse: a cantiga sugere uma identidade feminina que parece distante da visada subserviente mormente atribuída à mulher medieval: ainda que se trate de um recorte muito específico dessa identidade, a cantiga revela, pois, o desejo feminino como elemento de transgressão, já que ela, Marinha, "folga" nesse jogo de corpos, mãos e órgãos sexuais tanto quanto o próprio enunciador, o que em si pode nos indicar a rasura a um comportamento que pelo senso comum fazia equivaler prática social, moral e sexual. Trocando em miúdos: ainda que a identidade feminina representada na literatura medieval seja trilhada no silenciamento ou na "terceirização" de sua voz pela voz masculina, a cantiga faz parecer que as vivências do corpo pudessem talvez não corresponder a este silenciamento. Se a voz cala, o corpo fala, como bem já o pudemos perceber nas diversas cantigas 
em que a filha engana os cuidados da mãe para manter encontros amorosos com seu amado.

Seguindo a mesma linha da subversão às práticas sociais, amorosas e sexuais, o soneto de Manuel Barbosa du Bocage a seguir, bem poderia apontar para certa licenciosidade nos prazeres ou, ainda, talvez, para certas alternativas ao ideário de pureza e castidade defendidos socialmente há até bem pouco tempo:

Que eu não possa ajuntar como o Quintela

É coisa que me aflige o pensamento;

Desinquieta a porra quer sustento,

E a pívia trata já de bagatela.

Si n'outro tempo houve alguma bela

Que o amor só desse o cono pennugento,

Isso foi, já não é; que o mais sebento

Cagaçal quer durázia caravela.

Perdem saúde, bolsa, e economia;

Nunca mais me verão meu membro roto;

Está aí minha porral filosofia.

Putas, adeus! Não sou vosso devoto;

Co'um sesso enganarei a fantasia,

Numa escada enrabando um bom garoto.

(BOCAGE, 2003, p. 77)

No soneto de Bocage, dois aspectos parecem destoar: primeiro, o uso da forma poética soneto, cujo conteúdo normalmente versa sobre o aspecto sublime dos afetos e das emoções e, o segundo, decorrente disso, é seu uso satírico, o que destoa do conteúdo típico que nele vemos. Valendo-se de uma estrutura literariamente rígida, o poeta “ousa” lançar mão dela para 
versar sobre algo considerado grotesco, baixo e, até mesmo antinatural. A despeito daquilo que hoje seria considerado altamente transgressivo, abusivo e desrespeitoso - a pedofilia --, a voz que fala no poema encara sua atitude como uma alternativa ao fato de "alguma bela" puta àquela altura querer uma "durázia caravela” em lugar de oferecer-lhe o seu "cono penugento". A permissividade sexual, a parafilia, ganha seu contorno com o fato de o enunciador enganar a própria fantasia preferindo o ato escuso de ter prazer com um rapazinho a ver-se devotado ao ato sexual pago, seja ele como for, com uma prostituta, dando a entender ou que conseguisse sexo gratuito com jovens rapazes ou, ainda, que para a obtenção de seu próprio prazer não interessasse o gênero de sua parceria: “[...] é curta a idade, / E as horas do prazer voam ligeiras!”. (BOCAGE, 2003, p. 8I)

Ato sexual e forma poética, nesse caso, parecem se corresponder, uma vez que o considerado "natural" para um homem, àquela altura, seria de fato de desejar uma mulher e não um outro homem, ainda que mais jovem. Se considerarmos aqui a relação entre forma poética e formato sexual, o soneto revelaria a possibilidade de uma dupla subversão, já que esta forma poética não corresponderia ao que dela se esperava nem o ato sexual ali descrito, ao "usualmente" praticado. Da mesma maneira, ao aludir à prática de caráter sodomita, bem como ao ato pederástico (o sexo entre um homem mais velho, com barba, e outro impúbere), o poeta transgrediria ao sexualmente e eroticamente esperado para sua época, mas vincularia sua prática erótico-sexual ao momento de produção de sua obra, ou seja, a segunda metade do século XVII português. Lembro: tal período artístico valorizara o retorno aos temas e formas da antiguidade clássica, sobretudo a helênica e ao lançar mão do ato pederástico - valorado como forma educacional na antiguidade grega - o poeta fizera menção aos elementos estéticos valorizados àquela altura, apenas que se valendo, não da exposição de desejos "usuais", mas de uma prática social e cultural paralela à altura da escrita do poema e vivenciada naquela mesma antiguidade que o inspirara em outros poemas. 
Ou seja, reafirmando o modelo canônico e o aparente padrão cultural de sua época, o poeta usá-lo-á para expor poeticamente uma prática fora do padrão ou talvez discursivamente silenciada, mas talvez existente como subterfúgio, alternativa à preservação moral das relações mantidas entre homens e mulheres. Ao potencializar o valor estético seu contemporâneo, o poeta propõe fazê-lo transgressivamente, ato que se repetirá em inúmeros outros sonetos e poemas, nos quais o aspecto sublime da linguagem é substituído pelo uso supostamente grotesco, mas que a vincula ao real mais imediato daqueles seus possíveis leitores/fluidores. Essa intervenção no campo da expressão e da linguagem, que de fato não é um procedimento corriqueiro se considerado o todo poético de Bocage talvez não se trate apenas de uma tentativa de aproximar texto e leitor, mas, antes, de operar no poema uma naturalização que na verdade - e pela transposição dos campos do interdito e do ofensivo - apontaria para uma espécie de queering expressivo, no sentido em que ressignificaria tais termos ("cono", "cagaçal”, "porral”), reintroduzindo-os agora no campo esteticizado do poema e de maneira também esteticizada, fazendo do tosco e do grotesco, um expressão do sublime.

A linguagem, aliás, no seu uso performativo - na sua capacidade de criar, produzir e vivificar aquilo que nomeia - pode ser entendida como um procedimento queer, ao mesmo tempo em que, por outro lado, negativamente pode demarcar a normatividade que cerceia as noções de gênero. No caso, o gesto queer em questão estaria no fato de ao mesmo tempo em que o enunciador poemático potencializa seu impulso erótico-sexual e desnaturaliza o desejo ao demonstrar que para quem está excitado, pouco importaria o objeto, mas o exercício do “tesão". Por outro lado, este mesmo plano da expressão funcionaria negativamente, valorando "normas de gênero [que] operam ao ordenar a corporificação de certos ideais de feminilidade e masculinidade, ideais que são quase sempre relacionados à idealização do vínculo heterossexual” (BUTLER, 2003, p. 157), coisa que de fato acontece, posto que seja com uma puta ou com um garoto, mesmos permanecem desejo, gênero sexual e identidade masculina desse 
enunciador, todos eles intocados e como indiretamente afirmará em outro soneto: "Para que nos deu Deus porras leiteiras, / Senão para foder com liberdade?" (BOCAGE, 2003, p. 8I).

Aspecto que também parece ter relevo tanto na cantiga trovadoresca da Enes Cotom quanto nos sonetos de Bocage diz respeito aos tênues limites entre dois rótulos, aos que prefiro chamar "etiquetas culturais" ou "modos de ler": a nebulosa fronteira entre o erótico, o obsceno e o pornográfico. Susan Sontag (1987, p. 44-45) declarara em seu $A$ imaginação pornográfica que "é mais plausível apenas enfatizar que a pornografia ainda possui somente uma 'intenção', ao passo que a obra de literatura de real valor contém muitas", já que "o propósito da pornografia é inspirar uma série de fantasias não-verbais em que a linguagem desempenha um papel secundário, meramente instrumental”. Noutras palavras, o que a filósofa pareceu aludir diz respeito ao fato de que a pornografia tiraria o "valor" estético da linguagem literária (e de qualquer outra obra assim "rotulada”), já que tiraria os seus possíveis sentidos do campo da produção de significados, localizando-os no eixo, apenas, do significante. E nesse caso, o significante redundaria vazio, já que não seria capaz de fomentar as múltiplas flutuações próprias de um texto e que redundam da sua inserção na cultura. Cabe, claro, esclarecer que no caso da cantiga e do poema aqui lidos, os poetas pareceram optar por resvalar e transpor os limites entre o que parece permitido ao literário (o uso erótico da linguagem) e àquilo que lhe caracteriza - o uso apurado e intencional dessa mesma linguagem -, deslendo os códigos culturais e sociais próprios da época de circulação de suas obras. Essa desleitura do cânone por ele mesmo pode apontar para uma transgressão da linguagem literária, de forma a lembrar aos seus possíveis ouvintes/leitores/fruidores de que no mesmo campo onde o subjentendido e o jocoso operam, naquele mesmo onde o erótico se perfaz na linguagem, aquilo que está fora de cena - o obsceno, portanto - e que transgride a ordem pela naturalização do grotesco - o pornográfico retornaria aos poemas, agora, como forma e força estética, queerinzando a linguagem e a tornando queerente com o conteúdo semântico que veicula. 
Traduzindo: o sublime, o formativo, o assento nos aspectos valorativos e que poderiam contribuir para a construção de um ethos, surgiriam não apenas daquela literatura elevada, mas também redundariam da desleitura do sublime pelo grostesco e na instauração de outro sublime, nascido ali mesmo onde a linguagem poética optou pelo uso do chulo ou do que não caberia no poema, inclusos ali os corpos nele representados.

Seria muito propormos uma desleitura desse cânone moralmente formador, leitura indicada para a formação de cidadãs e cidadãos apenas considerando aqueles aspectos que denotariam o transgressivo do cânone ou um cânone transgressivo e que fosse apenas baseado na leitura de textos pertencentes a este mesmo cânone e considerados, ainda assim, satíricos, obscenos e jocosos. Entretanto, vale nos reportarmos aos modernismos português e brasileiro, tão afeitos às reformas dos padrões estéticos, mas moralmente inscritos, ainda, aos formatos de comportamento que pouco tinham de reformistas ou de vanguarda.

Investindo na temática do duplo, cara à literatura dos fins do século XIX e mesmo à sua Geração de Orpheu, Fernando Pessoa (I888-I935) no poema "Eros e Psique", o poeta modernista português, ao reafirmar uma tônica de sua poética, também impõe uma curiosidade aos seus leitores: no poema, a princesa que dorme é também o príncipe que a vai acordar. Podemos deduzir num primeiro momento que se trata, na economia da obra pessoana, de um gérmen da questão heteronímica, apenas que lançando mão dessa duplicidade pela introdução, no poema, de figuras que se espelham e que derivam entre ser eu e ser outro, ao mesmo tempo. ${ }^{4}$ Entretanto, há de ser observar que esse espelhamento se traduz na diversidade entre os gêneros sexuais e identitários entre as duas figuras que habitam o poema, o que redundaria, inclusive, na distinção entre esses dois corpos:

${ }^{4}$ Por heteronímia (do grego, "outro nome") entende-se o procedimento estético que consiste em criar personalidades poéticas diferentes da instância autoral e com características estéticas distintas entre si, ou seja, um outro do próprio autor. Cf. MARTINS, Fernando Cabral (org.). Dicionário de Fernando Pessoa e do Modernismo Português. São Paulo: Leya, 2010. p. 326-333. 


\section{"EROS E PSIQUE"}

Conta a lenda que dormia

Uma Princesa encantada

A quem só despertaria

Um Infante, que viria

De além do muro da estrada.

Ele tinha que, tentado,

Vencer o mal e o bem,

Antes que, já libertado,

Deixasse o caminho errado

Por o que à Princesa vem.

A Princesa Adormecida,

Se espera, dormindo espera,

Sonha em morte a sua vida,

E orna-lhe a fronte esquecida,

Verde, uma grinalda de hera.

Longe o Infante, esforçado,

Sem saber que intuito tem,

Rompe o caminho fadado,

Ele dela é ignorado,

Ela para ele é ninguém.

Mas cada um cumpre o Destino

Ela dormindo encantada,

Ele buscando-a sem tino

Pelo processo divino

Que faz existir a estrada. 
E, se bem que seja obscuro

Tudo pela estrada fora,

E falso, ele vem seguro,

E vencendo estrada e muro,

Chega onde em sono ela mora.

$\frac{192}{c m}$

E, inda tonto do que houvera,

À cabeça, em maresia,

Ergue a mão, e encontra hera,

Evê que ele mesmo era

A Princesa que dormia.

(PESSOA, I977, p. I8I)

Observemos num primeiro momento o processo de diálogo intertextual entre o conto tradicional "A bela adormecida”, apenas que agora com seu desfecho deslocado do tradicional "e foram felizes para sempre”, que redundaria num encontro com o outro, para o encontro com uma outra identidade, descentrada tanto do corpo como da própria subjetividade. Ao mesmo tempo, o poeta dialoga com o mito grego que se refere à conflituosa paixão entre Eros/Cupido (o Desejo) e a bela Psique, cujo fruto final será o nascimento da filha Hédone (o Prazer). As leituras mais contumazes apontariam para uma alegoria relativa à personificação da alma, aspecto metafísico relacionado a uma natureza feminina, envolvida entre as várias vicissitudes da existência, o sofrimento, o amor. Por outro lado, a incomum epígrafe do poema parece favorecer a um outro caminho:

E assim vêdes, meu Irmão, que as verdades que vos foram dadas no Grau de Neófito, e aquelas que vos foram dadas no Grau de Adepto Menor, são, ainda que opostas, a mesma verdade. (Do Ritual Do Grau De Mestre Do Átrio Na Ordem Templária De Portugal). (PESSOA, 1977, p. 18I) 
Que verdades seriam estas a serem "reveladas", que mesmo sendo opostas, são as mesmas e que são dependentes, inclusive, do grau de iniciação do indivíduo dentro de uma ordem como a dos templários? A epígrafe, como uma chave para um possível sentido do poema, parece apontar, justamente para a cisão/fusão do par falsamente opositivo masculino/ feminino: a verdade primeira (ser príncipe) corresponderia à outra (ser princesa), aparentemente opostas, mas, de fato, complementares. Numa palavra e dialogando com o próprio Pessoa quando "declara” ter "um temperamento feminino com uma inteligência masculina” (PESSOA, I990, p. 40), nada mais faria o príncipe do poema que sair em busca dessa princesa que dorme dentro de si mesmo, ou seja: a inteligência masculina revelaria, necessariamente, aquele temperamento feminino adormecido pelas diversas injunções sociais e culturais das primeiras décadas do século XX. E justo neste ponto tanto o apelo ao uso do duplo quanto a questão heteronímica parecem se laçar: a grande descoberta do Outro ("ele dela ignorado") em si mesmo talvez não passasse de fazer despertar em si, na verdade, uma Outra, princesa adormecida em suposta fragilidade silenciada ("ela para ele é ninguém") e que se impõe como urgência e destino do "Infante, esforçado". Longe, portanto, de alguma misoginia atribuída aos participantes de Orpheu (1915), Pessoa poderia querer enfatizar essas possibilidades de ser, inclusive, deixando claro a existência dentro de si de um duplo supostamente oposto, mas complementar, que se poria numa perspectiva supragênero. Mais uma vez aqui, "num vago masoquismo" (PESSOA, 1990, p. 40), que é a própria busca do amor da princesa (a linguagem) pelo príncipe (o corpo e o poeta), ou seja, a busca de si mesmo(a), o poeta rasuraria multiplamente a tradição: recomporia o sentido do mito grego; do conto tradicional e, na sequência, desfaria as antinomias culturais e sociais que oporiam os gêneros sexuais e identitários, apontando, ainda que sutilmente, para a existência de uma identidade queer que precisaria ser respeitada na sua particularidade: "é uma inversão sexual fruste” (PESSOA, I990, p. 40), só realizável no poema, ou seja, na 
linguagem, único lugar possível, àquela altura, em que se poderia efetivamente viver o corpo e não ser.

O poema "Eros e Psique" seria, de certa forma, um duplo metapoema, uma vez que reproduz a criação e o encontro deste(a) Outro(a) e de sua alteridade, ao mesmo tempo em que funciona como uma blague modernista, talvez um ponto de partida de uma certa tendência da literatura portuguesa de tematizar as questões que tangenciem às experiências de gênero e sexualidade, como se pode ver na contemporânea de Pessoa, Judith Teixeira, poeta portuguesa sequestrada do cânone, lésbica assumida:

$[\cdots]$

És linda assim: toda nua,

No minuto doce

Em que me trazes

A clara oferta do teu corpo

E reclamas firmemente

A minha posse...!

$[\cdots]$

Loira Salomé

De ritmos esculturais!

Vem mais nua

Esta madrugada!

Vem esconder-te na sombra dos meus olhos

E não queiras deixar-me...

Ai nunca, nunca mais!

(TEIXEIRA, 1996, p. 216)

Se em Fernando Pessoa vemos um corpo algo esvaziado de sua função erótica - e mesmo de seus afetos - sua contemporânea Judith parece 
perceber que diante de um panorama cultural e literário modernista, seria preciso demarcar também na expressão de corpos e dos silenciados e/ou obliterados uma posição que apontasse, naquele contexto, um procedimento de vanguarda: há uma certa performatividade do corpo e do gênero representada pela poesia de Teixeira, o que, para a sua época, tratava-se de uma experimentação e de um descompromisso com o atendimento à demanda particular de uma literatura de e para mulheres, que, claro, à altura denotava, ainda, um corpo aprisionado. $\mathrm{O}$ corpo que se expressa na poesia de Judith Teixeira, como o/os corpos de António Botto e os de Raul Leal - contemporâneos seus, experimentam e experienciam (insisto nas formas variadas de uma ação semelhante e entre semelhantes) seus desejos, afetos e impulsos e revelam a presentificação intensa da linguagem pela ação de um sujeito que a suporta. Nesse sentido, a construção do poema em Judith parece nascer da "friç̧ão" entre o excessivamente estético e o excessivamente comum, corriqueiro, mas elevado, que é o desejo; ou mais: uma fricção entre o seu corpo e o corpo de uma Outra, Salomé.

O modernismo português de certa forma deu aos seus artistas a opção entre despir e desnudar ou de encobrir e aprofundar certos "detalhes", como vemos no contraste entre Judith e Pessoa. No caso brasileiro, uma suposta desconformidade do corpo - plasticamente bem posta no Abaporu de Tarsila do Amaral - pareceu rondar boa parte de uma literatura produzida sob o signo da modernidade paulista: a tela da artista, ao potencializar os disformes pés da figura ali representada, encena o gesto metonímico que se vê, por exemplo, também, em Mário de Andrade no poema "Girassol da Madrugada". Um corpo estranhamente metonímico, cujo gênero identitário e sexual nunca aparece demarcado, a não ser pelos detalhes mais amplos, que o notabilizam apenas no campo do afeto e das sensações, mas jamais no espaço de um prazer que se possa ser, de fato, vivido. Esse "vazio" na representação do outro talvez encontre azo na disponibilização, pela Fundação Casa de Rui Barbosa, de uma carta trocada entre Mário de Andrade e Manuel Bandeira, onde o primeiro comenta sua "tão falada" homossexualidade: embora consiga transpor o 
modelo estético europeu em favor de uma dicção poética brasileira, Mário esbarraria, ainda, na dissociação entre prática estética e prática social, o que redunda, por exemplo, na constante interdição discursiva observada em alguns textos de sua autoria, como "Frederico Paciência". Diferentemente do que se viu em outros movimentos vanguardistas, inclusive latino-americanos, tanto o modernismo português quanto o brasileiro não viram razão entre associar estética e existência e nem em esteticizar a existência do artista. No caso, reitero, uma produção modernista ou vanguardista não corresponderia a um comportamento social e cultural de mesmos níveis e talvez decorra daí tanto a diluição de certos aspectos ligados às vivências do corpo, como também a sua metonimização: um corpo que é sempre recorte, recortado de seu gênero, de seus prazeres e de sua materialidade.

Muitas foram as leituras feitas do quinto entrecho do poema "Girassol da Madrugada”, cujos versos abaixo destaco. Entretanto, interessa a este ensaio, cujo foco, lembro, é o contraste entre as formas de representação canônica e os pontos de fuga neste e deste mesmo cânone, pôr em relevo a esta altura a desleitura proposta pelo próprio poema:

V.

Teu dedo curioso me segue lento no rosto

Os sulcos, as sombras machucadas por onde a vida passou.

Que silêncio, prenda minha... Que desvio triunfal da verdade,

Que círculos vagarosos na lagoa em que uma asa gratuita roçou...

Tive quatro amores eternos...

O primeiro era uma donzela,

O segundo... eclipse, boi que fala, cataclisma,

$\mathrm{O}$ terceiro era a rica senhora,

O quarto és tu... E eu afinal me repousei dos meus cuidados.

$[\cdots]$

(ANDRADE, I987, p. 339-34I) 
O título do poema já nos impõe uma quebra de paradigma, visto que um girassol, como indicado no próprio nome, seria uma flor cujo sentido não se perfaria na madrugada. Entretanto, se contrapusermos a existência da flor ao momento do dia em que ele é retratado, podemos inferir na construção de uma possibilidade: o girassol poematizado não poderia se não existir durante a madrugada, período em que a pouca ou inexistente luz traria a oportunidade de experimentar, inclusive, as coisas impossibilitadas, dando-lhes outro sentido, uma vez que o poema, resumindo a "perversa e imaculada correria dos fatos" declara que "De dia não seremos nada”, enfatizando a existência de uma relação apenas possível no sombreamento noturno. Na sequência, a instância que fala no poema passa a descrever o tempo vivido e os amores marcados na vida, agora olhados na maturidade e que perfazem uma relação estranha entre o tempo passado ("tive") e a sua permanência ("eternos"). Dentre os quatro amores descritos, o segundo assume-se como um interdito, um sombreamento na linguagem, posto que descrito como "eclipse, boi que fala, cataclisma": um amor que se aclara pela ausência solar, denotando-se na ordem do impossível e numa consequente transformação baseada num acontecimento arrasador, que modifica os padrões de percepção e marca a finitude de algo.

Por último, a caracterização de um "tu" onde "eu afinal me repousei dos meus cuidados" e de uma "eu" que se desprende de certos impedimentos e que se dispõe a viver seu afeto. Em nenhum momento do texto observamos alguma marca de gênero relacionada àquele "tu", o que pode resultar na naturalização baseada em toda a tradicional e sedimentada lírica amorosa romântica: se não há uma marca identitária, esse amor se devotaria a uma mulher. Entretanto, lendo o poema por outra clave e considerando ainda os níveis de sombreamento e interdição, a intencionalidade dessa caracterização obscura talvez redunde não no desenho de um amor heterossexual impossível, mas, justo, noutra possibilidade: não se poder dizer o nome do amor homossexual vivenciado pelo enunciador e disso decorreria o esvaziamento identitário a que tanto quem se enuncia quanto a "instância” a quem se dedica o poema estão submetidos. Ao lado disso, o "eu” que 
"narra” a existência desse girassol - signo masculino, aliás - também não se desenha na linguagem, sendo tanto ou mais vazio que o seu objeto amoroso. Se consideramos que girassol não é um elemento usual nos discursos amorosos, poderíamos, sem muito esforço, relacioná-lo ainda a uma marca de gênero masculino, visto que muito menos usual é usar uma rosa ou uma azaleia para descrever um homem em contexto amoroso. $\mathrm{O}$ poema ganharia, ainda, um relevo mais tenso quando imaginamos que a língua considera o grau zero, o vazio, a forma não marcada, o masculino e o singular, ou seja, enunciador e enunciado estão ambos relacionados à mesma experiência em termos de gênero e identidade - são ambos seres do sexo masculino - afirmação nada forçosa se consideramos os padrões da própria linguagem. Os vazios identitários, os obscurecimentos, os sombreamentos discursivos do poema nesse caso, apontariam a necessidade de diluir o canto amoroso diante de um possível leitor que - por uma série de questões sociais e morais - diminuiria o valor estético do poema caso ele explicitamente estivesse tematizando e se enunciando no masculino. O poeta, assim, conta com a naturalização da leitura e com a convenção social - "todo poema de amor é dedicado a uma mulher" - para, a partir dessas mesmas convenções e também as da linguagem, cantar seu amor pelo "pueril [...] olhar" de um rapaz. Numa palavra: parte-se das formas mais canônicas para se propor enunciações e atos de fala nada canônicos, contando-se, para isso, com as diversas naturalizações a que a literatura, como objeto da cultura, é submetida quando se trata de gêneros, identidades e de qualquer outro fenômeno ligado às sexualidades.

Retorno ao título e ao início desse ensaio. Para tanto, penso com Antonio Candido no seu artigo "Direito à literatura", que sendo a literatura algo atinente à condição humana, seja necessário pontuar em si as especificidades identitárias que caracterizam o humano. Nesse sentido, creio que a literatura, enquanto elemento de formação humana e como sedimento cultural deva dar direito à expressão do diferente, da diferença e à representação da diferença. Sobretudo porque, de maneira subliminar, essa diferença já conviva intrinsecamente silenciada no cânone ou sendo 
por ele tratada como uma questão menor e que não represente de maneira intensa as intencionalidades de uma cultura e de uma época. Mesmo que ainda sabendo que "Nem toda a gente gosta do diferente", como dirá Ana Luísa Amaral, e que textos como os lidos aqui podem contribuir a deformação dos leitores, cabe lembrar que como manancial, a literatura já esteve a diversos serviços, mas ainda não ao serviço da efetivo da diversidade.

\section{Referências}

AMARAL, A. L. Como tu. Vila do Conde/Portugal: QuidNovi, 2012.

ANDRADE, M. Poesias completas. Belo Horizonte: Itatiaia; São Paulo: EdUSP, I987.

BOCAGE, M. M. B. du. Poesia erótica. Lisboa: Dom Quixote, 2003.

BUTLER, J. “Critically Queer”. In: STRIFF, E. (Org.). Performance Studies. New York: Palgrave, 2003. p. 152-177.

CANDIDO, A. A Literatura e a formação do homem. In: CANDIDO, A. Remate de males. Campinas: Unicamp, 1999. Disponivel em: <http://revistas.iel. unicamp.br/index.php/remate/article/viewFile/3560/3007>. Acesso em: I2 fev. 2016.

JOUVE, V. Por que estudar literatura?. São Paulo: Parábola, 2012.

MARTINS, F. C. (Org.). Dicionário de Fernando Pessoa e do Modernismo Português. São Paulo: Leya, 2010. p. 326-333.

PESSOA, F. Obra poética. Rio de Janeiro: Nova Aguilar, 1977.

PESSOA, F. Obra em prosa. Rio de Janeiro: Nova Aguilar, 1990.

SONTAG, S. A vontade radical - estilos. São Paulo: Cia das Letras, 1987.

TEIXEIRA, J. Poemas. Lisboa: \& Etc, 1996. 